\title{
United States - Section 211 Omnibus Appropriations Act of 1998 (WT/DS176/AB/R) \\ A Comment
}

\author{
BY \\ ROBERT HOWSE \\ (University of Michigan Law School) \\ AND \\ DAMIEN J. NEVEN \\ (Graduate Institute of International Studies, Geneva and CEPR)
}

As usual the authors have divided their labor, based on expertise. In particular, the economic analysis in section 4 was the responsibility of Damien Neven; Robert Howse's own understanding of the costs and benefits of international trade law rules with respect to intellectual property protection in general depends on a rather different framework for analysing the problem. However, in so far as the legal and economic analysis of the Havana Club case itself is concerned, which deals only with trademarks as a form of IP protection, the authors are in agreement.

\section{Introduction}

The first part of the chapter (section 2) summarizes the facts of the case and the decision taken by the Appellate Body (AB). We emphasize two issues that the $\mathrm{AB}$ dealt with, namely the extent to which the TRIPs may contain a substantive obligation to grant protection to a trademark registered in another country and National Treatment. Section 3 discusses the notion of trademarks, the trade-offs involved in protecting trademarks and the extent to which trademark protection should be coordinated across jurisdictions. We observe that there is a strong case in favor 
of trademark protection in terms of alleviating moral hazard and adverse selection in product choices but we also identify instances where trademark protection can be abused. We also observe that the case for coordination across jurisdictions is less compelling for trademarks than other forms of intellectual property. We find that the international law of trademark protection is generally reflective of this insight, achieving only a minimum of harmonization and imposing constraints mainly when there is a significant external effect that would not be otherwise internalized, namely where the interests of foreigners are at stake.

Section 4 highlights and discusses the extent to which the $A B$ has limited the scope for harmonization of trademark provisions across WTO Members and in particular has rejected the positive integration that would be induced by some mutual recognition of trademark provisions across countries. Section 4 takes a broader perspective and discusses how national treatment affects firms' incentive to set intellectual property rights and the outcome that arises when national treatment applies. This outcome is compared with that which arises under alternative policy regimes and in particular under independent setting of IP rights for domestic and foreign holders and under mutual recognition. It is found that National Treatment is not as attractive as in other areas (like those covered by Art. III) and that mutual recognition, which has been rejected by the $\mathrm{AB}$ even in a limited form, has attractive features.

\section{Facts and procedure}

After initial consultations in 1999, the European Communities requested in 2002 the establishment of a panel to consider its complaint that a particular section (Section 211) of a US law, the "Omnibus Appropriation Act of 1998", was inconsistent with certain obligations of the US under the Agreement on Trade-Related Aspects of Intellectual Property Rights (the TRIPs agreement).

Section 211 deals with trademarks, trade names, and commercial names that are the same as or substantially similar to trademarks, trade names, or commercial names that were used in connection with businesses or assets that were confiscated by the Cuban Government on or after 1 January 1959 (see panel report, $\S 2.1$ ).

In the US, all transactions involving property in which a Cuban national has an interest require a license from the "Office of Foreign Assets Control" (OFAC). This office implements a specific regulation on the control of Cuban assets (the Cuban Asset Control Regulation, or 
CACR). The office can provide "general licenses" which effectively allow transactions that are specified in the regulation on Cuban assets.

Up until the promulgation of the law under dispute, a general license was available for the registration and renewal of trademarks previously owned by Cuban nationals, independently of whether trademarks had been confiscated. In other words, Cuban nationals could obtain trademark protection in the US.

The new law (Section 211) stipulates that no payment should be made with respect to trademarks that were used in connection with confiscated assets (part (a1)) and that no US court should grant rights to a Cuban national with respect to these trademarks (section (a2)). The CACR was then changed to reflect these new provisions and effectively prohibited the registration of and renewal of trademarks or trade names that were used in connection with confiscated assets unless the original owner of the mark has explicitly consented.

Hence, the effect of the new law, and subsequent changes in the CACR, is to deny to trademarks used in connection with confiscated assets the protection that is normally granted under US law.

Since in the US trademark protection is effected through common law (when associated with use) as well as statutes, Section 211 also contained a provision (b) which prevented US courts from enforcing protection of a trademark used in connection with confiscated assets on the basis of common law (the Trademark Act of 1946 - also known as the Lanham Act).

The (numerous) claims put forward by the EU can be sorted out broadly in four categories. The first category relates to the obligations that Members have under the TRIPS to grant protection to trademarks held by foreigners. The EU found three interpretations of TRIPS provisions which would contain such obligation.

First, the European Communities claimed that the Paris Convention (incorporated into TRIPs in this respect) contained an obligation to register and protect trademarks in the same condition ("as is") as in the original country of registration and hence that Section 211, which did not allow for the registration in the US of some trademarks as they are in Cuba, was inconsistent with this obligation. Much of the discussion by the panel focused on what should be understood by the same condition ("as is"). The panel found that it only referred to the form of the trademark. The EU appealed this finding.

Second, the European Communities claimed that Article 15 of the TRIPS stipulates a right to have a trademark protected, unless the decision 
not to protect falls within the scope of the exceptions and hence that Section 211 is in breach of this obligation (as it does not fall within the exceptions). The panel disagreed with the EU's reading of Article 15 and found that Section 211 was not inconsistent with Art. 15. The EU appealed this finding.

Third, the EU claimed that Section 211 was inconsistent with Article 16 of the TRIPs, which confers a substantive right to the owner of a mark to exclude third parties from using it when there is a substantial risk of confusion for consumers, because under Section 211, US courts cannot protect trademarks owned by Cuban nationals. The panel found that the EU had not met its burden of proof on this issue. The EU appealed this finding.

The second broad issue covered by the claims of the EU relates to national treatment and most favored nation clauses. The EU claimed that Section 211 was inconsistent with the national treatment obligation contained in Article 3 of the TRIPs and the most favored nation clause found in Article 4. The panel disagreed and the EU appealed those findings.

The third broad issue has to do with procedural rights. The EU claimed that Section 211 is inconsistent with Article 42 of the TRIPs, which requires WTO Members to establish fair judicial procedures concerning the enforcement of intellectual property rights. The panel accepted this claim.

Finally, the EU cast its claims both with respect to trademarks and trade names. The panel ruled that trade names were excluded from the TRIPs. The EU appealed.

Overall, this case thus raises essential issues of interpretation of the TRIPs and the $A B$ ruling has diverged from the panel on important aspects. Broadly speaking, the $\mathrm{AB}$ has affirmed the panel on the first issue, namely the extent to which WTO Members have the obligation to register trademarks. The $\mathrm{AB}$ limited the scope of these obligations and effectively ruled out mutual recognition. However, the $A B$ reversed the panel findings with respect to national treatment and MFN - emphasizing their importance. Finally, the $\mathrm{AB}$ made it clear that trade names were covered by the TRIPs.

\section{Background}

This section discusses the social and economic functions of trademark law (section 3.1) and international trademark rules (section 3.2). 
Section 3.3 then considers the positive international law of trademark protection.

\subsection{Social and economic functions of trademarks}

The economic literature of trademarks is relatively limited. Landes and Posner (2003) emphasize the role of trademarks in reducing search cost for consumers. ${ }^{1}$ They define a trademark as a "word, symbol or other signifier used to distinguish a good or service produced by one firm from the goods and services of other firms." They emphasize that a trademark allows for easier recognition and communication - effectively a shorthand way of recognizing a particular product (such that for instance, it is simpler to refer to "Sanka" than describe "the instant coffee which is produced by General Foods," to use their own example). These authors also point to the interplay between trademarks and the incentive to provide (or increase) quality, suggesting that "the benefit of trademarks in reducing consumer search costs requires that the producer of a trademarked good maintain a consistent quality over time and across consumers. Hence, trademark protection encourages expenditures on quality."

This argument can possibly be made a little more precise by referring to explicit models of quality choice ${ }^{2}$ with asymmetric information, and in particular the literature on experience goods. ${ }^{3}$ Experience goods are such that consumers only know the characteristics (or quality) of a product after they have consumed it. In those circumstances, repeat purchases will play an important role, as long as consumers can recognize the product that they have already bought when they contemplate additional purchases. Repeat purchase will help alleviate problems of moral hazard and adverse selection. Consider first the latter: firms selling high quality products may be able to induce consumers to try out their products by offering a low price for initial purchases, and charge a higher price when consumers have learned the quality of the product. This strategy will work (at a, so called, separating equilibrium) as long as firms selling low quality product do not have an incentive to mimic the behavior of the high

${ }^{1}$ See also Landes and Posner (1987).

${ }^{2}$ Landes and Posner ((1987) and (2003)) do provide a model which is however not best suited to tackle the issue of the role of trademarks as it is a static model, and hence does not account for consumers' learning about product attributes.

3 The models and results that we will use in the following paragraphs are standard in the IO literature. A detailed description can be found in any graduate textbook. 
quality firms. Whether this condition holds depends on the relative cost of providing low and high qualities and the margin that can be earned from selling high quality products at high prices when consumers have ascertained quality. However, for the mechanism to operate at all, it is necessary that consumers should recognize in later purchases the products that they have initially bought ${ }^{4}$ (something which is taken for granted by the literature). Trademarks will of course be instrumental in ensuring easy recognition. Trademark protection will also be necessary because firms selling low quality products will have an incentive to disguise their products to make them look like the high quality item that consumers have experienced. Consumers anticipating this will not try the products in the first place and the separation between low and high quality products will collapse.

Repeat purchases will also play an important role in the presence of moral hazard, such that firms have an incentive to pretend selling a high quality product but to deteriorate quality (after the purchase has been agreed). Firms might resist the temptation of selling a low quality item if this induces the consumers to make additional purchases (on which some margin will be earned). Similarly, if consumers entertain the possibility that the firm is somehow "honest" and would sell a high quality product in all instances, it might want to confirm these beliefs and establish the reputation of being an "honest" seller. In both instances, repeat purchases and the ability to recognize in later purchases the products that have been bought initially are essential. Trademark protection will also be necessary because competitors might have an incentive to take advantage of the reputation established by others firms (for instance, competitors with a higher discount rate).

To sum up, trademark protection seems important to ensure that repeat purchases help alleviate problems of moral hazard and adverse selection. The operation of mechanisms based on repeat purchases will also tend to increase welfare and bring benefits to consumers.

There are some striking differences between the role of trademarks and that of patents. Patents provide a stream of revenues to innovators and this, in turn, provides incentive to incur the fixed cost associated with

${ }^{4}$ Economides (1984) develops an argument along similar lines. He makes a distinction between frequently and infrequently purchased goods, suggesting that if trademarks are particularly useful for the former, they may also be useful in the latter case, in particular when a company sells both frequently and infrequently purchased goods (so the reputation spills over products). 
development of innovations. A key feature of intellectual property is precisely the fact that the cost of dissemination is typically negligible. ${ }^{5}$ In those circumstances, unrestricted use of the intellectual property by other firms would also lead to a net benefit ex post (the loss of profit for the innovator would be more than compensated by the increase in profit for the imitator and the increase in consumer surplus). Intellectual content thus has the feature of a public good and in a second best world where patents are the only instrument, the design of patents will balance the benefits that accrue from marginal innovations with the deadweight loss on infra-marginal ones.

In the case of trademarks, the matter would appear to be somewhat different. In the context of the models discussed above, the firm which establishes a trademark incurs a cost (it foregoes profit in the short term) in the hope of reaping profits in the long term. However, unlike what happens with innovations, unrestricted use of trademarks would actually lead to a net cost ex post; the imitator would appropriate some of the surplus that would accrue (ex post) to the firm which induces repeat purchases and consumer surplus would fall (repeat purchases would no longer take place). The improved communication which is sanctioned by trademark protection does not seem to have the feature of a public good. Unlike patents, whose extension imposes a deadweight loss, trademark protection would thus appear to confer benefits such that they should be unrestricted, at least in the framework that we have considered so far.

Special features of trademark laws and in particular the dependency of the entitlement to a trademark on use, not simply invention, are also best understood in terms of this framework. Only if a trademark is in use is there a danger that consumers will be misled by someone other than the original holder attaching it to their products or services. In addition, traditionally, it has been a requirement in establishing a trademark violation, to show the possibility of consumers being misled.

The case for trademark protection should however not be generalized beyond the confines of the particular models that we have referred to. Indeed, there are clearly some circumstances where it may be attractive to restrict trademark protection. Consider for instance a small variation of the models above in which entry by a more efficient producer is feasible at a later stage. This producer may have the same incentive as the original

5 That is also to say that there is no rivalry in the consumption of intellectual content (a good whose production only requires to incur a fixed cost is effectively a public good). 
producer with respect to the provision of high quality goods and repeated purchases. Trademark protection will however bar entry and might impose a net cost.

More generally, it would appear that trademarks can play an additional economic role, beyond that of securing repeated purchases and allowing for the operation of mechanisms which solve moral hazard and adverse selection. Consider for instance an environment where there is no asymmetric information regarding the characteristics of the products but in which a consumer's willingness to pay for the product can be increased through advertising. ${ }^{6}$ The natural reference here is a model with endogenous sunk cost à la Sutton and the Rolex watch may provide a suitable illustration; the mechanical features of such watch can arguably be observed by consumers and can be imitated by other producers. Assume that advertising conveys no information about the product and has solely the effect of raising consumers' willingness to pay for the watch (because it conveys a signal of a particular life style). The welfare consequences of trademark protection in this case are not as clear-cut as those discussed above. In particular, the effect on consumer surplus of allowing for imitation ex post is less clear, as consumers who enjoy the mechanical features of a Rolex watch but do not value the signal would benefit at the expense of those who consider it as highly valuable. ${ }^{7}$ In other words, the rationale for protecting the effect of advertising does not seem as compelling as protecting the operation of repeat purchases.

There are also some circumstances where trademark protection will be clearly unattractive. For instance, trademark protection could possibly be used in order to raise entry barriers and protect rents. This will arise if the trademark covers some generic product - for which asymmetric information is unimportant (imagine that the expression "pain killer" is given trademark protection). This could be the result of trademark protection being captured by producers' interests. The legal doctrines in some jurisdictions that allow the curtailment of trademark protection once the mark is deemed to take on a "generic" meaning may actually reflect the concern of not protecting producer rents.

${ }^{6}$ Economides (1984) discusses this as an instance where a "mental image" is associated with the product, so that the product acquires a new characteristic.

${ }^{7}$ Economides (1984) refers to this as a form of allocative inefficiency which arises from the fact that particular characteristics (the mental image and the mechanical features) are tied in fixed proportions. 
Finally, it is worth noticing that in some circumstances, trademarks might have a public good aspect. This arises because, as symbols or communicative signs, trademarks become important features of the "Lebenswelt", as it were - they represent a significant part of the language of human social and even political communication. Protecting the trademarks could then lead to suppression of freedom of expression, and welfare reducing declines in human creativity. Consider Warhol's Campbell's Soup can, and the use and distortion of marks as a form of political parody or satire by anti-globalization activists (see Rosemary Coombe (1998); Beebe (2003)).

To sum up, if there is a presumption in favor of trademark protection when it contributes to mechanisms which solve problems of moral hazard and adverse selection, there are also some circumstances where trademark protection is less attractive.

The trade-off between the benefits from additional trademarks and the cost of trademark protection on infra-marginal ones is also such that extensive trademark protection is probably desirable. The terms of the trade-off are different from what is normally found for innovations, given that the cost of trademark protection on infra-marginal products is likely to be much less than the cost of patent protection on infra-marginal innovations. Trademark protection may be costly only when trademarks have a public good aspect as a means of fostering communication.

\subsection{International trademark rules}

How do these welfare trade-offs play out when we move from the domestic context to the international one: what do they imply about the justification or lack thereof for global trademark protection?

The external effects that patent protection induces across jurisdiction will be discussed later. In this section, we will emphasize that in defining patent protection in the domestic market for domestic (or foreign) firms, a domestic government will not consider the benefit that accrues to foreign consumers from additional innovations. In addition, in defining its policy towards foreign firms, a domestic government will not consider the benefit that accrues to foreign firms.

When it comes to trademarks, the matter is a little different because the external effect to foreign consumers may not be important. If we confine ourselves to the most favorable case for trademarks (as protecting repeated purchases), a trademark policy towards firms operating in the domestic market will mostly affect the range of products sold to domestic 
customers and not that sold to foreign customers. Indeed, one expects, as a first approximation, that the range of product sold in the foreign market will be determined by the protection that can be obtained abroad (of course, to the extent that foreign consumers may be exposed to domestic trademarks through distance media like the internet, there will still be a spillover effect across countries). As in the case of patents however, a domestic government will not consider the profit accruing to foreign firms in deciding whether to grant trademark protection in the domestic market. Still, the benefit to domestic consumers may be enough to justify a decision to grant trademark protection to the foreign firms (independently of the rents accruing to the firms). ${ }^{8}$

Overall, external effects across jurisdictions in the case of trademarks are less of a concern than in the case of patents. They only arise to the extent that foreign profits are not taken into account and may thus lead to insufficient protection to foreign firms.

The issue still arises whether in those circumstances, the foreign government might be able to invoke the interest of domestic consumers in order to obtain trademark protection. There is nothing as such illegitimate in a country making a claim to care for the welfare of consumers in another country (international human rights and labor law are illustrations of the principle that human concern does not stop at national boundaries).

Still, the external effect that we have identified would be best addressed by an international trademark law concerned with fair treatment of foreigners, in other words, with preventing abusive or discriminatory application of trademark law to aliens. Thus, it could be considered to be a lex specialis of general international law on the protection of aliens. In this environment, one would expect to see little substantive harmonization of domestic trademark laws, but rather the exclusion of certain kinds of grounds or pretexts for disposing of trademark applications by aliens, grounds or pretexts that sound in arbitrariness or discrimination. While formally appearing as a kind of at least "negative" harmonization, this kind of international trademark law might better be understood as a set of specialized rules for the protection of aliens.

Our discussion of external effects has so far focused on circumstances where trademark protection is most likely to be attractive in terms of

${ }^{8}$ For instance, if trademark protection is a discrete instrument. With a continuous instrument, the degree of protection to foreign firms will be less. 
welfare. If trademarks are used in order to raise entry barriers, or protect advertising aimed at raising consumers' willingness to pay, the external effects will be different and may be closer to those normally associated with non-tariff barriers which shifts rents between domestic and foreign producers.

Finally, note that besides the internalization of external effects, international trademark law could be fundamentally concerned simply with reducing those enforcement costs of trademark law that arise from transboundary economic activity. In such cases, each jurisdiction would preserve its sovereignty to make such choices for its own consumers.

\subsection{Positive international law of trademark protection}

With these conceptual considerations in mind, we now turn to the positive international law of trademark protection. The locus classicus for such law is the Paris Convention.

The trademark provisions of the Paris Convention are not preceded or prefaced by any preamble or statement of objectives (nor does the Paris Convention itself have Preamble). Instead, the trademark provisions in the Convention begin with the assertion of a default rule in favor of domestic sovereignty: "The conditions for the filing and registration of trademarks shall be determined in each country of the Union by its domestic legislation." (6.1). Article 6 then goes on to state some specific limitations on this default rule, listing a limited number of grounds on which it is impermissible to refuse to register and protect a trademark held by an alien. These impermissible grounds include: that the mark was not registered originally in the alien's own country (6.2); that the mark differs from the mark registered in the country of origin "only in respect of elements that do not alter its distinctive character and do not affect its identity in the form in which it has been registered in the said country of origin"; grounds that relate to "the nature of the goods"(7).

In addition, there is a general obligation to "refuse and to cancel the registration, and to prohibit the use, of a trademark which constitutes a reproduction, an imitation, or a translation, liable to create confusion, of a mark considered by the competent authority of the country of registration or use to be well known in that country as being already the mark of a person entitled to the benefits of this Convention and used for identical or similar goods." (6bis(1)).

Considered individually and in relation to each other, these various obligations suggest a quite limited degree of positive harmonization of 
domestic trademark law. There is a default rule in favor of domestic sovereignty, and the only general substantive norm, reflected in 6(bis)(1) is that of avoidance of consumer confusion.

The limited harmonization implied by these obligations is in line with the absence of strong external effects discussed above. The emphasis on consumer confusion is also consistent with the main motivation for trademark protection discussed above. From that perspective, it should be noted that the language "liable to create confusion" would probably exclude from the obligation in 6(bis)(1) uses of trademarks in general social and political communication (parody etc.), since such uses do not confuse consumers searching for goods, almost by definition. Nor would it require the protection of "generic" names, since in such instances most consumers may be simply expecting that the similar or identical product has certain generic characteristics, rather than a particular quality associated with it being manufactured by the original user of the mark.

Apart from 6(bis)(1), which introduces an element of positive harmonization, the other trademark rules in the Paris Convention, do not really go beyond the objectives of fair and non-discriminatory treatment that characterize a lex specialis on protection of aliens. They seem to aim at insuring aliens' demands for recognition and registration of their marks are not denied or frustrated on grounds that could invite arbitrary or discriminatory behavior by governmental authorities in other states.

Apart from the Paris Convention there are a range of other international legal instruments that relate to trademark protection, such as the Trademark Law Treaty (1994) and the Madrid Agreement Concerning the International Regulation of Marks. These Agreements seem aimed primarily at the reduction of transboundary enforcement costs of trademark law. They deal with many technical aspects of registration of marks outside the jurisdiction, and related matters. To some extent, by specifying procedures to be used by national authorities in dealing with aliens, these Agreements could also, in certain aspects, be considered lex specialis of the law of protection of aliens.

This brings us to the trademark provisions of the WTO TRIPs Agreement, the relevant provisions in the Havana Club dispute.

The Preamble to TRIPs recognizes "underlying public policy objectives" for the protection of intellectual property in domestic legal systems. It does not single out any particular purpose or objective as far as trademark law is concerned. Article 7 of TRIPs acknowledges that complex welfare trade-offs may be implicated in the way and extent to 
which intellectual property is protected, and states the principle that "The protection and enforcement of intellectual property rights should contribute to the promotion of technological innovation and the transfer of technology ... in a manner conducive to social and economic welfare, and to a balance of rights and obligations." Article 8.1 states that Members have a general police power to adopt health and nutrition measures and promote the public interest in sectors of vital importance to their socioeconomic and technological development subject only to any specific constraints contained in the textual provisions of TRIPs. Taken together, these various provisions suggest that interpretations of TRIPs should not be based upon a presumption of the intent to harmonize intellectual property laws, especially beyond the extent to which it would be clearly "conducive to social and economic welfare," but instead a presumption that TRIPs preserves domestic regulatory autonomy and diversity subject to certain precisely specified textual constraints.

The provisions of TRIPs that apply to trademarks largely follow the Paris Convention, discussed above; and the general TRIPs obligations of National Treatment and MFN also apply to trademarks. A WTO Member may deny registration to a trademark on any ground that does not "derogate from the provisions of the Paris Convention" or is explicitly prohibited by TRIPs provisions themselves.

The only clear instance of substantive harmonization of trademark law to be found in TRIPs is the requirement that anyone other than the original holder be excluded from using the mark, where there the consumer is liable to be confused (16(1)). However, TRIPs is slightly more harmonizing than the Paris Convention, by virtue of establishing a presumption of confusion in the case of identical goods and services. Also TRIPs 16(1) does not require that the mark be well known in order to benefit from this general norm of protection. On the other hand, unlike Paris Convention 6bis, which refers to "interested party", only the "owner" of a trademark may assert exclusive use, under 16(1) of TRIPs (an aspect of that provision which as we shall see will be quite crucial to the AB's disposition of the appeal). Finally, 16.1, and all the other provisions of TRIPs on trademarks, are however subject to a general exceptions provision, which states: "Members may provide limited exceptions to the rights conferred by a trademark, such as fair use of descriptive terms, provided that such exception take account of the legitimate interests of the owner of the trademark and of third parties" (Article 17). TRIPs explicitly acknowledges that a WTO Member may make trademark protection contingent on use, and that 
trademark protection may be cancelled due to non-use, subject to certain conditions. The TRIPs obligations on enforcement of intellectual property rights apply mutatis mutandis to trademarks. The provisions can be understood as a lex specialis of the law of protection of aliens, as well as going to the reduction of enforcement costs across national boundaries.

In sum, none of the provisions of TRIPs related to trademarks evidence any intent to substantially harmonize trademark law beyond the minimal extent evidenced in the Paris Convention. The minimum harmonization which is contemplated by the international law of patent protection is also broadly consistent with the economic analysis discussed above which has emphasized that external effects across jurisdictions may not be as important for trademark protection as for other instruments. The emphasis given by international law to the protection of aliens is also appropriate given that the main external effects in patent protection which would not otherwise be internalized arise with respect to the profits accruing to foreign producers.

\section{The $\mathrm{AB}$ ruling}

\section{Article 6 quinquies of the Paris Convention}

The EC appealed the panel's finding that the United States legislation did not violate Article 6quinquies of the Paris Convention, incorporated into the TRIPs agreement through TRIPs 2.1. This provision reads, in part: "Every trademark duly registered in the country of origin shall be accepted for filing and protected as is in the other countries of the union, subject to the reservations indicated in this article ..."(emphasis added).

These reservations include situations where the trademark may "be of such a nature as to infringe rights acquired by third parties in the country where protection is claimed"; where the mark "is devoid of distinctive character" or has become essentially generic; and where the mark is "contrary to morality or public order, and in particular, of such a nature as to deceive the public."

Placing considerable emphasis on the expression "as is" in the first paragraph of Article 6quinquies, the panel found that Article 6quinquies did not create a self-standing obligation to register a trademark, subject to a limited number of reservations or exceptions, but rather only required that, if domestic law otherwise permitted registration of the mark, it must 
be registered "as is", i.e. in exactly the form presented to the authority upon registration. Thus, Article 6quinquies did not derogate from a Member's general right under Paris Convention 6.1 to determine the conditions for the filing and registration of trademarks by its domestic legislation", except as regards the form of the mark. In consequence, the challenged US legislation did not violate Article 6quinquies, in as much as the restrictions it placed on registration were not related to the form of the mark.

The grammar of 6quinquies is logically consistent with either the broader meaning asserted by the EC ("You must register this trademark, and not only that, you have to register it as is unless one of the exceptions applies") and the narrower meaning discerned by the panel ("if your domestic law otherwise permits the registration of this trademark, you are obliged to register it in exactly the form that it is presented, subject to the exceptions).

Thus, the Appellate Body rightly found that the "ordinary meaning" of the words in 6quinquies was not sufficient to resolve the issue, and went on to explore the "context" of 6quinquies. The Appellate Body then determined that the "context" supported the narrower interpretation made by the panel.

The first contextual consideration that the Appellate Body adduced was Paris Convention Article 6.1, the general default rule of domestic sovereignty: the $A B$ suggested that "if Article 6quinquies $A(1)$ were interpreted too broadly, the legislative discretion reserved for Members under Article 6(1) would be significantly undermined." This is an important interpretive move by the Appellate Body. In effect, the $A B$ uses 6.1 as evidence of the limited or modest aspiration of the Paris Convention with respect to the substantive harmonization of trademark laws. Some might criticize the $\mathrm{AB}$ here, since 6.1 explicitly limits the default rule of domestic sovereignty, by stating it is subject to the obligations in the Paris Convention itself, and therefore, 6.1 merely begs the question of how narrow or broad those obligations might be, i.e. how much they cut into the default rule of domestic sovereignty. Yet such an alternative reading of 6.1 would reduce the provision to a triviality: "you are permitted to do what is not prohibited to you." That would simply restate what is already obvious, at least since the Lotus case, namely that the sovereignty of states is presumed to be unlimited, unless bounded by specific rules of law.

Thus, to give 6.1 an effective meaning, it must be interpreted as signaling that, in fact, such derogations from domestic sovereignty as 
are provided for in the Paris Convention, will be narrow, bounded, and clearly expressed.

It is to be noted that there are provisions in other WTO Agreements with a rather analogous structure to that of Paris Convention 6.1. For example, the Preamble of the TBT Agreement states that "no country should be prevented from taking measures necessary to ensure the quality of its exports, or for the protection of human, animal or plant life or health or for the prevention of deceptive practices, at the levels it considers appropriate, subject to the requirement that they are not applied in a manner which would constitute a means of arbitrary or unjustifiable discrimination between countries where the same conditions prevail or a disguised restriction on international trade, and are otherwise in accordance with the provisions of this Agreement."(emphasis added). A reading of this provision analogous to that which the $A B$ makes of Paris Convention 6.1 would have the result that the treaty interpreter should be very reluctant to read the provisions of TBT in such a way as to limit a Member's right to choose the appropriate level of regulatory protection or intervention, unless the text cannot be read any other way. This would defeat expansive readings of certain provisions of TBT, which suggest a proportionality test, for example, even though such a test is not explicitly specified in the language in question (see Howse and Tuerk, 2001 on TBT Article 2.2, footnote 91, p. 317, criticizing the expansive interpretation of the late Bob Hudec).

Similarly, according to SPS 2.1, "Members have the right to take sanitary and phytosanitary measures necessary for the protection of human, animal or plant life or health, provided that such measures are not inconsistent with the provisions of this Agreement." By stipulating domestic regulatory autonomy as a general right, SPS 2.1 implies that any limit to that right must be clearly established by the textual provisions of SPS, and that the treaty interpreter must avoid interpretations of SPS provisions that would result in largely uncircumscribed or unbounded interferences with the general right.

To return to Havana Club, the AB went on to illustrate the wisdom of a narrower reading of 6quinquies by reference to the jurisdiction-shopping effects if the broader EC reading were adopted. As the AB noted, there are two means by which a holder of a trademark from a Member of the WTO/ Paris Union can seek trademark protection in the territory of another Member. Pursuant to Article 6 of the Paris Convention, it can seek directly to register the mark with the authorities of that other Member, in which case such registration is, on account of 6.1 , subject to such 
conditions as exist in the domestic law of that other Member. ${ }^{9}$ Alternately, the $\mathrm{AB}$ noted, a trademark holder of a Member could first register the mark with that Member's authorities, and then seek registration from the authorities of the other Member, pursuant to Article 6quinquies. If the $\mathrm{EC}$ interpretation were correct, the $\mathrm{AB}$ conjectured, then a mark holder could do an end run around the domestic legal requirements of the other Member, by going the route of Article 6quinquies, which, on the EC reading, requires registration and protection of the mark, subject to the limited exceptions in that Article itself. The AB suggested that thus "a national of a Paris Union country could circumvent the "use" requirements of a particular regime by registering in the jurisdiction that does not impose "use" requirements.

The problem with the $\mathrm{AB}$ reasoning here is that Article 6quinquies itself states that "In determining whether a mark is eligible for protection, all the factual circumstances must be taken into consideration, particularly the length of time the mark has been in use."(C.1) (emphasis added). This clearly implies that whatever else Article 6quinquies means, it does allow for the possibility that a Member could make a decision that a trademark is not eligible because of lack of use. Thus, the AB is wrong that, on the EC reading of Article 6quinquies, the mark holder of a Member could avoid the use requirement of another Member, through resorting to Article 6quinquies. Moreover, whatever reading is adopted of Article 6quinquies, this Article, as incorporated into TRIPs, is subject to the explicit acknowledgement in Article 19 of TRIPs that use may be required to maintain a registration, subject to the conditions stated in that Article.

We emphasize however that the error of interpretation in this particular step in the AB's reasoning does not really mar the compelling logic of its general view that interpreting 6quinquies in the way proposed by the EC would introduce a requirement of minimum positive harmonization, or mutual recognition, not warranted by the context of 6quinquies and the overall structure of the TRIPs trademark regime. Once having interpreted 6quinquies in context, the $\mathrm{AB}$ felt it necessary to address one particular argument of the EC in favor of its alternative, broader reading, namely that the exceptions listed in 6quinquies would only make sense if its application were broader than to just the form of the mark. The

${ }^{9}$ It should be added, a Member could also, quite apart from registration, simply demand the substantive minimum of protection afforded by the Convention Article 6bis/TRIPs Article 16/1, namely exclusion of other users where the consumer is likely to be confused, provided it could otherwise establish in some way that it is "owner" of the mark. 
$\mathrm{AB}$, in reply, simply asserted: "The form of a trademark may be devoid of distinctive character within the meaning of paragraph 2 ... Equally the form of a trademark may be contrary to morality or public order, or of such a nature as to deceive the public within the meaning of paragraph 3."

Finally, the $\mathrm{AB}$ introduced an additional contextual consideration, namely an agreed interpretation of Article 6quinquies as it appeared in the original Paris Convention of 1883, which made clear that the provision in question only prohibits exclusion from registration based on the form of the mark, leaving Members free to deny registration, based on other conditions or criteria in their domestic laws. However, this agreed interpretation was omitted in subsequent versions of the Paris Convention.

The $\mathrm{AB}$ was clearly unsure about relying on the agreed interpretation in these circumstances, so it states "... [W] e simply observe that our interpretation ... is not inconsistent with this interpretation." Was it correct, under the Vienna Convention rules, to avert to the 1883 agreed interpretation as part of the "context" of the Paris Convention as incorporated into TRIPs? We believe so. According to VCLT 31(2)(a), "context" includes "any agreement relating to the treaty which was made between all the parties in connection with the conclusion of the treaty." VCLT $31(2)$ (a) applies not only to agreements that are explicitly made an integral part of the main treaty, but to any agreement connected with the conclusion of the treaty. The fact that the instrument incorporating the agreed interpretation was not made an integral part of subsequent versions of the treaty, does not as such defeat its status as an "agreement ... made in connection with the conclusion of the treaty." And, as the $\mathrm{AB}$ notes, there was no attempt at any time to explicitly revoke or repudiate the agreed interpretation, or to alter it. In our view, the VCLT would have allowed the AB to rely to a greater extent than it did on the agreed interpretation, which it appeared to treat almost as supplementary means, like travaux, which could normally only be used to confirm an interpretation based on primary sources.

There is a way in which the $\mathrm{AB}$ could have acted with greater judicial economy in its consideration of the meaning of Article 6quinquies. It could have held that even if, arguendo, the expansive interpretation by the EC of the Article were correct, the US legislation would nevertheless have fallen within the "third party rights" exception, which allows a Member to exclude registration and protection where the trademark is of such a nature as to infringe rights acquired by third parties in the country 
where protection is claimed..$^{10}$ Under the US legislation at issue, clearly, rights have been acquired by the original owners of confiscated assets, and their heirs and assigns. It is in the name of these third party rights that the US was excluding registration under the challenged legislative provisions. This is reinforced by the fact that should the third parties waive their rights the legislation would permit registration and protection to proceed.

Why then did the $\mathrm{AB}$ decide to venture an interpretation of a complex legal provision that it wasn't required to make, and indeed one based in part on what seems to be an incomplete and erroneous reading of aspects of the Paris Convention? The $\mathrm{AB}$ seems to have thought it important to shut the door to the use of TRIPs to expand the scope of legally mandated intellectual property protection, beyond that strictly and clearly mandated by the treaty language. Here one cannot wonder if there was a broader policy context at least in part influencing (if sub-consciously) the judges: the context of debates over globalization and intellectual property, where many aspects of TRIPs have been criticized as the product of industry capture, extending IP protections at the global level beyond what could be justified on the basis of either domestic welfare in all WTO Member states, or global economic welfare).

Importantly, the defeat of the EC's broad reading of Article 6quinquies also helps to close the door to the use of TRIPs to grant trademark protection in other circumstances than those where they reduce consumer search cost.

To see this, it is important to compare carefully Paris Convention 6bis and 6quinquies as interpreted by the EC. 6bis, as already discussed, does create a substantive right for an "interested party" to insist that the authorities of a Member country prohibit on their territory the use of a mark well known in the country of origin, where that use is liable to confuse consumers. Moreover, it is this substantive right to a certain level of trademark protection in other Member countries that is, in a slightly modified form, restated in Article 16(1) of TRIPs. If, as the EC proposed, 6quinquies were to be read as creating a right to registration and protection, subject to a set of exhaustively listed exceptions, a new substantive right would be created that would rival and exceed that in Paris 6bis/ TRIPS 16(1). Since 6quinquies does not limit the meaning of "protection" to the enforcement of exclusive use where other use might confuse

10 This would be somewhat analogous to the way that the $A B$ avoided deciding the question of territorial nexus under Article XX(g) in Shrimp/Turtle I. 
consumers, and indeed does not define "protection" at all, the EC interpretation would allow the door to open at the WTO on expansive views of trademark protection now being advanced by corporate interests in the courts of various domestic jurisdictions, with varying degrees of success, e.g. anti-dilution. These expansive views are widely questioned in the economics literature as discussed above. The TRIPs Agreement itself mandates readings of that Agreement that would make intellectual property protection "conducive to social and economic welfare." On the basis of economic analysis, an expansion of trademark protection beyond what is required to support the consumer search cost reduction function might well not be "conducive to social and economic welfare."

\section{TRIPs 15.1 and 15.2}

TRIPs 15.1 states certain grounds on which a mark may not be denied eligibility for trademark protection. Namely, WTO Members may not exclude from eligibility for trademark protection a sign because of the kind of sign that it is - thus whether the sign is constituted of words, letters, numerals, figurative elements, combinations of colors, or a mix of any of the above, it shall nevertheless be eligible for registration. There thus seems to be some overlap between TRIPs 15.1 and Paris Convention 6quinquies, which requires that a trademark be registered as is.

TRIPs 15.2 provides that 15.1 "shall not be understood to prevent a Member from denying registration of a trademark on other grounds, provided that they do not derogate from the provisions of the Paris Convention (1967)."

Much in the manner in which it sought to discern in Paris Convention 6quinquies a substantive right to trademark protection, the EC argued that 15.1 provided not merely for negative harmonization (stating certain discrete grounds on which Members were not permitted to distinguish between trademarks as eligible or not eligible for protection), but rather stated a right to have a trademark protected, unless the decision not to protect was well within one of the exceptions permitted by the Paris Convention.

Unlike the case with Paris Convention 6quinquies, the ordinary meaning of the words in 15.1 excluded the interpretation being urged by the EC. As the Appellate Body noted (paragraph 155), Article 15.1 deals with the question of when a mark may be "eligible" for or "capable of" receiving trademark protection. The EC's reading would in effect eliminate those words from the treaty text, such that 15.1 would say not when a mark must be eligible for protection, but rather when there is an obligation to provide the protection. 
However, the $\mathrm{AB}$ went further, and sought support for its (obvious) reading of 15.1 from the "context" of 15.2, which states that Members can nevertheless deny registration of a trademark on "other grounds", provided that they do not derogate from the Paris Convention. As the $A B$ pointed out, the reference to "other grounds" suggests that all 15.1 does is to state one particular kind of grounds on which Members cannot refuse to consider a trademark eligible for registration and protection, namely what kind of signs or symbols it consists of. The $\mathrm{AB}$ further cited as "context" for its interpretation, TRIPs 15.4, which establishes that a trademark may not be denied registration simply because of the nature of goods or services that it designates. As the $\mathrm{AB}$ noted, if, as the EC suggested, 15.1 constituted a general obligation to register and protect trademarks, rather than stating a single prohibited ground for denying registration and protection, then 15.4 would be superfluous; there would be no need to state prohibited grounds one by one, since by virtue of 15.1 there is instead (on the EC theory) a general obligation to register and protect, subject to certain defined exceptions.

Even though this disposed of the EC's appeal on this issue, since no violation could be found (the US legislation in question having nothing to do with the kind of sign that composes the mark), the $\mathrm{AB}$ made a point of going on to consider and reject the EC's interpretation of 15.2. The EC's view of 15.2 was that it limited the legal right to refuse registration and protection to those situations explicated stated as exceptions in the Paris Convention (or TRIPs itself). The AB, however, regarded 15.2 as an affirmation of the default rule of domestic sovereignty in Paris Convention 6.1. In other words, Members are free to determine the conditions of trademark registration and protection, subject to certain explicit prohibited grounds, which they are forbidden to use to discriminate between trademarks with respect to eligibility for registration and protection.

Here, the $\mathrm{AB}$ made an explicit decision to jettison judicial economy, it would seem, in order to make clear as guidance for future panels the overall nature of TRIPs as far as trademarks are concerned; TRIPs is not an agreement for substantive harmonization, or mutual recognition, but merely reinforces or reaffirms the negative integration commitments of the Paris Convention.

\section{TRIPs Article 16.1}

If there is some element of positive harmonization or integration in the TRIPs trademark provisions, it would have to be found in Article 16.1, 
which as noted in an earlier section of this chapter, is similar to Paris Convention 6bis, in conferring a substantive right to exclude third parties from using the mark for identical or similar goods or services such that there is a likelihood of consumer confusion. Unlike Paris Convention 6bis, TRIPs 16.1 requires a presumption of likelihood of confusion where the sign being used is identical to the original mark.

There is, however, a crucial difference between Article 16.1 and Paris Convention 6bis. Paris Convention 6bis does not depend on the concept of ownership. Instead, it states that the mark "must be considered by the competent authority of the country of registration or use to be well known in that country as being already the mark of a person entitled to the benefits of the Convention..." Thus, who can exclude others from using a mark appears to depend on the decision of the authorities of the jurisdiction of initial registration and/or use.

By contrast, neither TRIPs 16.1, nor any other provision of TRIPs for that matter, defines how, or by whom, the question of ownership is to be determined. In the absence of any explicit provisions on these matters in either TRIPs or the Paris Convention, the panel had asked the Director General of the International Bureau of WIPO for an expert opinion on whether the Paris Convention contained an implicit definition of "ownership." The Director General answered in the negative.

The Appellate Body approved the panel's deference to this opinion from WIPO. This is an example of the kind of "institutional sensitivity" that Howse and Nicolaidis recommend in dispute settlement (Howse and Nicolaidis, 2003: Howse, 2000). The legitimacy of the dispute settlement organs is enhanced when they are prepared to defer to the judgment of non-WTO international institutions with expert competence in a specialized legal regime that intersects with the rules of the WTO. What is striking here, though, is the AB's endorsement of such deference not just with respect to factual matters, but also in legal interpretation; this qualifies what seemed in some earlier cases the AB's tendency to consider itself competent to interpret the relevant law of other regimes, including municipal law, as if it were interpreting WTO law itself (provided of course that the other law was properly before it as relevant to the application of a WTO Agreement; India - Patents, EC-Bananas).

On the other hand, the absence of an implicit definition of ownership in the Paris Convention, as determined by the official experts of that legal regime, does not excuse the Appellate Body from attempting a contextual definition of ownership as it relates, not to the obligations of the Paris Convention, but to those in TRIPs itself. The EC pointed to a number of 
provisions of TRIPs that, contextually, seemed to suggest that the owner of a trademark, at least presumptively, was the undertaking that had originally used or registered the mark, and anyone who had legally acquired the mark from that original "owner".

The very nature of 16.1 is that of an obligation that rights established in one jurisdiction (the home jurisdiction) be recognized by the authorities of other WTO jurisdictions; thus, there is arguably no need to define ownership. Ownership and other pre-conditions for the establishment of a trademark are naturally governed, in the logic of a recognition provision, by the laws of the home country, absent any explicit minimum international standards. Viewed in this way, the conclusion that the Appellate Body draws from the silence on ownership in TRIPs is perverse - namely, that the jurisdiction obliged to recognize a trademark right duly established in the home country gets to decide who is a bona fide owner of the right.

A recognition and enforcement regime such as that in 16.1 is of course appropriately subject to exceptions of a public policy nature; and in a case such as Havana Club the United States could arguably invoke such an exception, if the decision of the host country to recognize a certain individual or entity as an owner violated the public policy of the United States. But that is quite another matter than inferring a general default rule that the country of recognition and enforcement, not the country where the rights are established in the first place, has full latitude to determine who is a trademark "owner."

As was discussed earlier in this chapter, economic analysis questions whether positive harmonization of the substantive norms of trademark law can be justified on welfare grounds. The strongest economic case for positive harmonization is that global consumer welfare is likely to be enhanced if every country was required to take steps to avoid use of marks so as to confuse consumers. In interpreting TRIPs 16.1 the way it does, the $\mathrm{AB}$ seems to shrink from accepting even that degree of positive harmonization that would, broadly speaking, be supportable on the basis of economic analysis. But there are important reasons of democracy, reasons that relate to the legitimacy of WTO law and adjudication, for taking as seriously as the $\mathrm{AB}$ does a declared default rule of domestic sovereignty.

At the same time, by virtue of TRIPs Article 2.1, Article 6bis of the Paris Convention is incorporated into TRIPs. While substantially overlapping with TRIPs 16.1, there is nothing in 16.1 that explicitly states that it alters and surpasses Paris Convention 6bis. Since Paris Convention 6bis confers, 
not on the "owner" of the mark but rather on an "interested party" the right to demand that the authorities of a Member enforce exclusive use where the mark is "considered by the competent authority of the country of registration or use to be well known in that country as being already the mark of a person entitled to the benefits of the Convention ...", the AB could have gone on to complete the analysis, as it were, applying to the facts Paris Convention 6bis, which contains a substantive right closely analogous to that in 16.1. Paris Convention 6bis appears to resolve the kind of situation where ownership of the mark is contested across different jurisdictions (here the US vs. Cuba) by deferring to the views of the authorities in the country of registration and use, assuming that that is a country where the authorities consider it to be well known that the mark is already the mark "of a person entitled to the benefits of the Convention..." (the panel below had rejected the EC claim that the US legislation violated Paris Convention 6bis, on rather unclear grounds, that seem related to a concession of the EC to the US position that 6 bis in no way precluded each country's authorities from making their own decision about how confiscation might affect the determination of whether a mark was a "mark of a person entitled to the benefits of the Convention").

In any case, the AB's holding that domestic sovereignty to restrict the ownership of trademarks remains essentially unconstrained by TRIPs is of no small importance. On the AB's logic, through ownership measures, a government can impose a wide range of responsibilities on an entity that wishes to have the status of "owner" of a mark, including social responsibilities. If the US view of the Cuban revolution and the Castro regime is a legitimate basis to make a determination of who owns a trade mark, then denying a mark, for example, to an entity that manufactures marked goods in sweatshops that violate internationally recognized labor standards might equally be legitimate, if not more so. (See Katherine Van Wezel Stone, 1999).

Moreover, one may ask if the analysis of "ownership" by the AB in Havana Club might not have implications for the interpretation of TRIPs obligations in respect of other forms of intellectual property. Take the case of patents. Article 28.1 of TRIPs requires that certain exclusive rights on the "owner" of a patent. Article 27 of TRIPs lists specific grounds on which Members may or may not exclude patentability. But TRIPs says nothing about the determination of who is the "owner" of a patent and is therefore entitled to the exclusive rights named in TRIPs 28.1. Of course, the National Treatment and MFN obligations in TRIPs would apply to determinations of ownership under domestic law. 
As for the Berne Convention, as incorporated into TRIPs, it appears to have a similar default rule in favor of domestic sovereignty over the conditions of substantive protection of intellectual property as does the Paris Convention in respect of trademarks. Thus Article 27.5 of the Berne Convention provides: “... any Contracting State is free to apply, when determining the patentability of an invention claimed in an international application, the criteria of its national law in respect of prior art and other conditions of patentability not constituting requirements as to the form and contents of applications."

If thus WTO Members are free (subject to the National Treatment and MFN obligations of TRIPs) to determine the criteria or conditions for someone to be an "owner" of a patent, this has major implications for the ability of developing countries, for instance, to insure that patent protection does not conflict with their development needs. ${ }^{11}$ Technology transfer, acceptance of price controls, etc. could all be imposed as conditions for an entity to be recognized as an "owner" of a patent, and thereby the beneficiary of the rights enumerated in TRIPs 28.1.

In sum, the finding of the Appellate Body concerning the significance of ownership not being defined or specified in TRIPs with respect to trademarks has significant promise for rebalancing the TRIPs Agreement in a manner conducive to answering many of the critiques of TRIPs by developing country activists and governments. The problem is that the AB's approach reposes on an erroneous interpretation of TRIPs 16.1 - an interpretation that ignores the fundamental structure and nature of the obligation in 16.1 as an obligation of recognition and enforcement of substantive rights established before the authorities of another jurisdiction.

\section{TRIPs Article 42}

Article 42 requires that WTO Members afford to holders of intellectual property rights "civil judicial procedures concerning the enforcement of any intellectual property right covered by this agreement." Article 42 goes

11 At the same time, depriving a foreign economic actor of the status of "owner" of certain intellectual property rights might constitute, for example, a violation of the customary international law of investor protection, and in some cases might violate provisions of trade or bilateral investment treaties, depending on how they are worded. There could be circumstances where a deprivation of "owner" status for example might be considered an "expropriation" or a denial of "full protection and security." 
on to stipulate certain minimum level of due process to which "right holders" are entitled.

The EC argued that the US legislation in dispute took away this entitlement from Pernod, by essentially taking away from it the status of a "rights holder." Thus, the legislation, while not taking away the standing of someone claiming to be a "rights holder" to assert their substantive claim, would allow that claim to be defeated such that the court might never get to the application of the general provisions of trademark law, including those in TRIPs.

The $\mathrm{AB}$ rightly held that the legislation went to the substantive not procedural validity of trademark claims, and therefore did not violate the procedural rights in Article 42. While a US court might, as a matter of judicial economy, rule against the substantive claim of a trademark holder on the basis of the legislation in dispute, without going on to consider the merits of the claim otherwise, the $A B$ held that to do so did not violate any of the procedural rights in Article 42; nothing in the legislation in dispute authorized or mandated the US courts not to apply the guarantees of fair procedure in the Rules of Evidence and federal civil procedure legislation. Only after determining, on the basis of rules of fair procedure, that a right holder did not "own" the mark in question, would a court, on the basis of the legislation in dispute, find its claim to be invalid.

\section{Paris Convention Article 8}

Article 8 of the Paris Convention provides that "A trade name shall be protected in all the countries of the Union without the obligation of filing or registration, whether or not it forms part of a trademark." Article 8 is one of the provisions of the Paris Convention incorporated into TRIPs by virtue of TRIPs Article 2.1. Article 2.1, however, states that this incorporation is "in respect of Parts II, III and IV of TRIPs." Since trade names are not dealt with as a separate kind of intellectual property from trademarks in Part II of TRIPs, the panel held that Paris Convention Article 8 was not incorporated into TRIPs; it interpreted the words "in respect of ..." as limited or circumscribing the scope of the incorporation of the Paris Convention into TRIPs. Both the US and the EU appealed this finding, which the panel also sought to sustain by reference to the negotiating history of TRIPs.

The Appellate Body correctly observed that Article 8 - which deals with trade names exclusively - was explicitly chosen as among those articles mentioned in 2.1. If would be nonsensical to include Article 8 in the list of Articles of the Paris Convention incorporated in TRIPs, and then 
completely nullify the incorporation by virtue of the language "in respect of ..." The $\mathrm{AB}$ found that the language "in respect of ..." could be given a meaning that would avoid this result.

Here, the $\mathrm{AB}$ was, we believe, on solid ground. The principle of effectiveness in treaty interpretation requires that the interpreter seek a meaning that gives effect to all of the relevant treaty provisions, and to do so before claiming a contradiction or ambiguity that would justify recourse to the negotiating history.

As the $A B$ suggested, the language "in respect of ..." need not mean that a form of intellectual property protection dealt with in an incorporated provision of the Paris Convention need appear in the titles or headings of Parts II, III or IV of TRIPs. As the AB observed, the Patents section of TRIPs refers to a sui generis system of intellectual property as an alternative to patentability in the case of plant varieties. Such an provision could not be defeated just because there is no heading in Part II of TRIPs on sui generis patent protection.

In the case of trade names, Article 16.1 of TRIPs makes it clear that a mark may not be denied protection because it consists merely of words, including personal names. To this extent, Part II of TRIPs does protect trade names, either as marks or part of marks. The fact that none of the substantive provisions in TRIPs Part II mentions trade names as a distinct form of intellectual property may well be because the drafters considered the protection provided to trade names as distinct from marks in Article 8 of the Paris Convention to be sufficient. The incorporation of Paris Convention Article 8 might well be the reason why it was not necessary to deal with trade names independently of marks in Part II; thus, to defeat the incorporation of Paris Convention Article 8 into TRIPs on the grounds that trade names are not mentioned separately in Part II would be utterly perverse. These considerations, in our view, provide strong support for the Appellate Body's decision to reverse the panel, and find that Article 8 of the Paris Convention is indeed incorporated into TRIPs.

Having so decided, it should be noted, the $A B$ chose not to exercise its discretion to complete the analysis, the panel having not made any findings of fact concerning the claims on trade names (since the panel viewed them as excluded from TRIPs altogether). It is likely, based on its interpretations of other provisions of TRIPs and the Paris Convention in this ruling that the $\mathrm{AB}$ would have found Article 8 to be largely, if not entirely, procedural in character, stating only that protection of trade names may not depend on the prior formalities of filing and registration, 
but without specifying when and at what level Members are required to provide substantive protection to trade names.

\section{National Treatment and MFN}

TRIPs incorporates the National Treatment obligation of the Paris Convention Article 2(1), which states: "Nationals of any country of the Union shall, as regards the protection of industrial property, enjoy in the other countries of the Union the advantages that their respective laws now grant, or may hereafter grant to nationals."

With respect to successors-in-interest, those who acquire a trademark from the original owner, the contested US legislation on Havana Club proved that US courts shall not recognize, enforce or validate any rights by a "designated national" (where of course the trademark was at one time the property of a confiscated entity); "designated national" is defined in the Regulations pursuant to the legislation not only as Cuba or any Cuban national of any foreign country (that is, non-United States nations) who are successors-in-interest to a designated national.

The United States persuaded the panel that although these provisions explicitly barred certain foreign nationals only from the assertion of trademark rights in the US Courts, in practice there was no denial of National Treatment, since it was also the consistent practice of the US authorities to deny recognition of these rights where held by US nationals, and since there were other statutory and international law bars to the recognition of rights acquired in connection with confiscated property, which would equally function as a bar to US nationals and foreign nationals attempting to assert such rights in the US courts, quite apart from the legislation being challenged in Havana Club.

The Appellate Body reversed, finding that the Havana Club legislation constituted an additional hurdle to the recognition of trademark rights that was imposed only on certain foreign nationals, but not on US nationals. While the $A B$ recognized that there were serious obstacles faced by US nationals in the same situation, there remained a hypothetical possibility that these might be overcome in a given case, resulting in better treatment of the US national in question, in relation to the foreign national who would, in like circumstances, now face the additional obstacle in the Havana Club legislation.

The $\mathrm{AB}$ ruling seems to be a relatively straightforward application of the spirit and letter of the GATT $S .337$ panel ruling; there, the panel suggested that in cases of explicitly different, and prima facie less favorable, treatment of foreign products in a particular law, in order for the 
defendant to successfully claim that a full comparison of the overall treatment of the relevant foreign products shows that the latter are not discriminated against, there must be certainty that, in every instance, the factors extrinsic to the particular legal provisions being challenged would fully balance or neutralize any less favorable treatment that would result from those particular legal provisions. This seems a heavy burden to meet, but again it must be recognized that here, in Havana Club, as in 337, foreigners were being singled out explicitly and categorically in the law itself.

With respect to original owners of trademarks attempting to assert their rights in the United States, the Appellate Body found that if there were "two separate owners who acquired rights, either at common law or based on registration, in two separate United States trademarks before the Cuban confiscation occurred" and these trademarks were the same as or similar to a Cuban trademark used in connection with a business that was confiscated, and the one owner was American and the other Cuban, only the Cuban national would be affected by the regime in the Havana Club legislation. Thus, again there was explicit discrimination against foreign, in this case Cuban, nationals.

The United States pointed out however that the Havana Club legislation did not apply to trademarks registered in the United States prior to the existence of Section 515.527 of the CACR. The AB responded that this "does not address the discrimination against Cuban nationals who are original owners of trademark rights in the United States based on common law."

Unlike with respect to successors-in-interest, where it is obvious that all designated foreign nationals face at least an additional formal hurdle under the Havana Club legislation, the discrimination discerned by the $\mathrm{AB}$ in the case of original owners seems to depend entirely upon a hypothetical, i.e. the existence of a class of persons, Cuban nationals who are original owners of trademarks rights in the United States based on common law, which trademarks are the same or similar to trademarks used by businesses then confiscated by Cuba. Finding less favorable treatment of foreigners based upon an entirely hypothetical situation of certain (possibly non-existent foreigners) in relation to US nationals, seems at odds with the $\mathrm{AB}$ ruling in Canada-Periodicals, where the $\mathrm{AB}$ faulted the panel for basing its analysis of National Treatment on comparisons based on purely hypothetical situations.

In addition, Cuba was not a party to the Havana Club litigation and the question arises as to the appropriateness of the AB's implicit conclusion 
that the obligation of National Treatment towards Cuban nationals is one that the United States owes to the EC or the entire WTO Membership not just to Cuba. The AB did not even address the question of whether or not National Treatment, in TRIPs or the Paris Convention, is an obligation of that nature, i.e. erga omnes partes. (See Pauwellyn, 2002). Certainly, if one were to view National Treatment in these instruments as a kind of lex specialis of the law on the treatment of aliens, there would be a strong presumption against erga omnes partes, because, traditionally under the law of protection of aliens, only the state of which the alien is a national can assert a claim against another state based on its treatment of that alien. Matters in Havana Club may not be that simple, however, because the meaning of "Cuban national" seems to extend to persons who were Cuban nationals and are currently residing outside of Cuba in third countries, including possibly the EC. From the perspective of the National Treatment obligation, these persons might well be properly considered EC "nationals" even if they might fall within the definition of "Cuban national" in the statute.

This brings us in fact to the MFN violation claimed by the EC. In the case of original owners, the Havana Club legislation, by singling out Cuban nationals (not other foreign nationals as is the case with the legislation as it applies to successors-in-interest) discriminates between Cuban nationals and original owners from other WTO Members. The United States responded that a Cuban original owner could be "unblocked" under different legislation; however, the $\mathrm{AB}$ pointed out that 1) only Cuban nationals resident in the US were automatically "unblocked"; 2) Cuban nationals resident in Cuba cannot be unblocked;

3) Cuban nationals resident in the EC may be "unblocked" but must go through an additional procedure. The difference in treatment between 2 and 3 does in fact show racial discrimination of a kind prohibited by the MFN obligation. But the worse treatment of Cuban nationals residing in the EC than Cuban nationals residing in the US, 1 and 3, arguably illustrates why it might have been reasonable for the $\mathrm{AB}$ to find a National Treatment violation in respect of treatment of original owners, even without Cuba being a litigant, or without directly addressing the issue of erga omnes partes.

National Treatment and mutual recognition As discussed above, the $\mathrm{AB}$ ruling confirms the importance of National Treatment in the TRIPs. It also takes the view that mutual recognition of intellectual property rights should not go beyond the form in which it was filed. 
This section discusses how National Treatment affects the incentive to set intellectual property rights and the extent to which it improves efficiency. We also consider the incentives that mutual recognition would trigger and compare the outcomes arising out of national treatment and mutual recognition.

In order to discuss this issue, we develop a framework that can deal with patents and copyrights as well as trademarks. As discussed above, trademarks, unlike patents, do not involve important public good aspects. In the context of the framework that we develop below, this will generally yield a higher level of protection for trademarks, relative to innovations. But the essential ingredients of the model remain the same. The case of trademark can thus be obtained as a special case, in which the balance between the marginal cost and the marginal benefit of extending IP protection yields a high level of protection.

As indicated above, the external effects across jurisdiction may also be less pronounced in the case of trademarks than in the case of patents. This arises because trademark protection in one country, which allows for the profitable sale of a particular product item, will not yield benefit to foreign consumers. Trademark protection in the foreign country will be necessary in order to trigger profitable sales abroad. In the case of innovation, once produced, it will be sold abroad even if there is no protection. In other words, benefits abroad are not contingent on the existence of IP protection abroad for domestic products.

However, the absence of one external effect across jurisdictions will not change qualitatively the results discussed below. Domestic governments will still have less of an incentive to grant IP protection to foreign firms than domestic firms and the effect of both national treatment and mutual recognition will be qualitatively unchanged. In what follows, we will refer to the broader framework, involving IP rights and innovations, keeping in mind that trademarks can be obtained as a special case.

We find that National Treatment effectively pools incentives with respect to domestic and foreign innovations. It prevents government from discriminating between IP rights with different perceived returns and as a consequence leads to a sharp fall on the IP rights granted to domestic firms. We find that National Treatment is unlikely to improve much over the uncoordinated outcome in which each government sets different IP rights for domestic and foreign innovation. By contrast, we find that mutual recognition has attractive features; in a symmetric environment (where countries have the same size), mutual recognition actually achieves the outcome that would be selected by a central 
government, which internalizes all external effects across countries. This arises because under mutual recognition, a domestic government induces the foreign government to select towards domestic firms the IP policy that it would have selected if it had internalized external effects across countries.

At first glance, the fact that National Treatment does not seem very efficient may come as a surprise, given that national treatment is often considered as a reference in the area of non-tariff barriers (Art. III). This may reinforce the extent to which National Treatment should be seen in the context of the Trademark provisions of TRIPs as part of a lex specialis with respect to the fair and non-discriminatory treatment of aliens, rather than a mechanism for insuring welfare maximizing levels of trademark protection.

Hence, before considering in detail how different regimes will affect IP rights, we briefly compare the effect of National Treatment in the area of non-tariff barriers (Art. III) and the area of intellectual property rights.

(i) National Treatment: NTBs versus IP rights

Let us first consider National Treatment in the area of NTBs, for instance a product regulation, which raises the costs of foreign firms, relative to those of domestic firms. Such barriers can be attractive for the domestic government to the extent that they affected the competition between domestic and foreign firms and reallocated rents in favor of domestic firms.

As is well known from the literature on strategic trade policy, the governments involved (assumed to maximize domestic welfare) face an incentive structure, which conforms to a prisoner's dilemma - in which the dominant strategy is to introduce product regulations which favor domestic firms. The outcome is inefficient, and both countries are worse off relative to the situation where neither country introduces non-tariff barriers.

In this instance, the source of the inefficiency is the (pecuniary) external effect that the introduction of a non-tariff barrier imposes on the profits of the foreign firms. This external effect is not internalized by the governments involved. A treaty between governments which bans the implementation of the non tariff barriers will also naturally remove the inefficiency but it will require a strong mechanism of compliance as the government will always have an incentive to introduce such non-tariff barriers, in the hope that they will remain unnoticed or fall through the cracks of the legal system. 
Let us now consider the recognition of intellectual property rights. The recognition of intellectual property rights to foreign firms has two aspects: first, by granting intellectual property rights to foreign firms, the domestic government will again affect the allocation of rents between domestic and foreign firms, as long as domestic and foreign products associated with the intellectual property rights are not independent. If these products compete, ${ }^{12}$ by granting intellectual property rights to foreign firms, domestic governments will make foreign products less attractive - as domestic users will have to pay some royalties. This will also increase the profits of domestic firms, so that the rents to both domestic and foreign firms will increase. Such a policy may thus only be attractive to the domestic government if it gives an important weight to profits - relative to consumer surplus. In what follows, we will mostly abstract from this first aspect of intellectual property rights.

The second aspect is associated with the design of an intellectual property policy. The design of intellectual property rights strikes a balance between the distortion that they involve with respect to existing products and the benefit that would accrue from additional innovations (see Nordhaus, 1969). In evaluating the distortion that intellectual property will impose on domestic products, a domestic government will only consider the deadweight loss. In other words, it will consider the profit to domestic firms as a transfer from consumers. However, with respect to the intellectual property rights granted to foreign firms, foreign profits will not be counted as part of the country's welfare and hence the cost of an increase in price associated with an intellectual property regime will include the entire reduction in consumer surplus. Hence, the domestic government will have less of an incentive to grant intellectual property rights to foreign firms relative to domestic firms. As in the case of non-tariff barriers, the external effect that the domestic policy has on foreign profits is not internalized.

With respect to the benefit of intellectual property rights, a national government considering new domestic innovation will only take into account the benefit accruing to domestic consumers (at the margin a new innovation will yield no profit). It will neglect the external effect to foreign consumers. Similarly, in considering the benefit that might

12 The opposite would occur if products are complement. 
accrue from extending intellectual property rights to foreign firms, a domestic government will only consider the benefit that will accrue to domestic consumers.

Overall, in designing an intellectual property regime for domestic firms, a domestic government will fail to consider benefits accruing to foreign consumers and hence will provide excessively low protection to domestic innovations. This bias in favour of excessively low protection will persist in designing intellectual property for foreign firms; in addition, when it comes to foreign firms, the cost of intellectual property will be biased upwards as foreign profits will not be considered. This will reinforce the bias in favor of excessively low protection towards foreign firms.

Let us now consider national treatment, whereby domestic governments commit to provide to foreign firms the treatment that they provide to domestic firms. As observed by Scotchmer (2002), national governments have little incentive to adopt this policy unilaterally: the additional profits that they would grant to foreign firms is unlikely to be compensated by the domestic benefit that would accrue from the development of new products abroad, at least if the domestic country is relatively small. This will also arise independently of whether foreign countries have themselves adopted a regime of national treatment. As in the case of non-tariff barriers, the uncoordinated outcome will thus involve insufficient protection of foreign firms and the implementation of a regime of national treatment will require a strong compliance mechanism.

The question of the extent to which National Treatment will improve efficiency is less clear-cut. National treatment effectively ensures that intellectual property rights are the same for domestic and foreign firms - despite the fact that underlying incentives are different for foreign and domestic firms. It does not directly address the underlying sources of inefficiencies either. A policy addressing the external effects would have to ensure that national governments consider the profit accruing to foreign firms when intellectual property rights are raised and consider the benefits to foreign consumers from new innovations. National Treatment does not do either of these. It imposes the same IP rights on both domestic and foreign firms.

These consequences will be discussed in more detail below. At this stage, it is worth emphasizing that the analysis of national treatment should not be imported from the area of non-tariff barriers (Art. III) to that of TRIPs. If the incentives faced by governments with respect to 
the imposition of non-tariff barriers and with respect to the extension of intellectual property rights to foreign firms are similar, the parallel should not be extended further. Whereas NTBs have to do with the allocation of rents between firms, the extension of intellectual property rights to foreign firms has to do with the provision of public goods (in a second best world). National treatment can be expected to have different consequences in these two environments.

(ii) A simple model of innovation and trade

In order to investigate some of the properties of the outcomes induced by national treatment and mutual recognition, we will develop a simple benchmark model of trade and innovation. This benchmark model will abstract from many issues and in particular will assume that products developed domestically and abroad are independent. More precisely, any product developed in one country will have a market in both domestic and foreign countries and will not compete with other existing or future innovation. In addition, countries will not "compete" with respect to the development of innovations. Each country can be thought of as being completely specialized in a particular innovation segment. ${ }^{13}$ This model thus abstracts from all issues of rivalry between innovations (both within and across countries) to focus on the issue of coordination between countries in the provision of public goods.

Both Scotchmer (2002) and Grossman and Lai (2002) have analyzed the non-cooperative choice of IP policies under national treatment. They consider richer models in which innovations compete (Grossman and Lai (2002)) or in which countries face a coordination problem in the development of new innovations (Scotchmer (2002)). These authors however focus on the interplay between countries in defining their IP policies under national treatment and do not attempt to evaluate national treatment relative to other policy regimes.

There are two countries, 1 and 2. There is a technology, common to both countries such that new products can be designed at a cost $k$ where $k$ is uniformly distributed in the $[0,1]$ interval and such that for each cost $k$ there is a density $\gamma=1$ of new products that can produced (the set of potential innovation is thus given by $[0,1] \times[0,1]$. If the

13 Alternatively, one can think of this model as describing an environment where there are innovation races for each product across countries and in which each country has an intrinsic advantage in developing a range of innovations. 
two countries develop innovations simultaneously in the same cost range, each country will obtain a share $\gamma_{i}$ of the corresponding innovations (with $\gamma_{1}+\gamma_{2}=1$ ). These shares might be thought of as reflecting the relative efficiency of the two countries in developing new products.

In each country, there is a demand for each new product which is denoted $P_{i}=a_{i}-Q_{i}$, all products are independent (neither substitute, nor complement) and once developed can be produced at constant (zero) marginal cost.

An IP policy towards innovators selling products in country i can then be modeled as a level of rent, $\Pi_{i}$. In turn, in the absence of rivalry between innovations, any level of rent can be determined by a price level $P_{i}$, where $\Pi_{i}=P_{i}\left(a_{i}-P_{i}\right)$, so that an IP policy can be seen as the choice of a particular price level for each new product. Note that profits can be seen as discounted flows over time so that the choice of a particular price level can also be interpreted as a patent length (an increase in the patent length will increase profits and the deadweight loss and reduce consumer surplus).

Each country's government will select at most two IP policies, one towards domestic innovations and one towards foreign innovations. We denote $\tilde{P}_{i}$ as the IP policy of country i, which applies to its domestic innovators, whereas $y_{i}$ will denote the IP policy which applies to foreign innovators.

There is free entry in the production of innovation so that any innovation which is profitable is produced. The range of innovations which takes place is thus determined by the flow of profits which arise from IP rights in both countries (that is from IP rights granted to domestic firms by the domestic government and the IP rights granted to the same firms by the foreign government). Let us denote $k_{i}\left(\tilde{P}_{i}, y_{j}\right)$ as the marginal innovation in country $i$. This marginal innovation is determined by the level of profits accruing from both domestic and foreign IP rights, with $k_{i}\left(\tilde{P}_{i}, y_{j}\right)=\tilde{P}_{i}\left(a_{i}-\tilde{P}_{i}\right)+y_{j}\left(a_{j}-y_{j}\right) .{ }^{14}$ The range of innovation which is produced in country $i$ is thus given by $\left[0, k_{i}\left(\tilde{P}_{i}, y_{j}\right)\right]$.

Let $\operatorname{CS}\left(\tilde{P}_{i}\right)$ and $\operatorname{DWL}\left(\tilde{P}_{i}\right)$ denote respectively the consumer surplus and deadweight loss that accrue as a function of a domestic IP policy

${ }^{14}$ We assume that there is no arbitrage across countries so that the demands for any given products are independent across countries. 
in country i. Standard calculation yields that

$$
\begin{aligned}
\operatorname{CS}\left(\tilde{P}_{i}\right) & =\frac{\left(a_{i}-\tilde{P}_{i}\right)^{2}}{2}, \operatorname{DWL}\left(\tilde{P}_{i}\right) \\
& =\frac{\tilde{P}_{i}^{2}}{2}, \text { and } \operatorname{CS}\left(\tilde{P}_{i}\right)+\operatorname{DWL}\left(\tilde{P}_{i}\right)+\Pi_{i}\left(\tilde{P}_{i}\right)=\frac{a_{i}^{2}}{2}
\end{aligned}
$$

The same expression applies, mutatis mutandis, for IP rights granted to foreign firms.

We consider four policy regimes: first, we derive the choice of an optimal IP policy by each country, with respect to domestic and foreign firms, in the absence of any coordination. Second, we consider the choice of an IP policy under national treatment (whereby domestic and foreign firms have to be treated alike). Third, we consider the choice of an IP policy under mutual recognition (whereby foreign firms have to be treated in the same way as in their domestic base). For reference, we also derive the policy that would be chosen by a central authority, which internalizes all external effects across countries.

(iii) Independent IP policies

As shown by Nordhaus (1969) (see also Grossman and Lai (2002)), the optimal choice of an IP policy (or patent length) will balance the benefit from new innovations with the distortions that the IP policy implies ex post on existing products, as long as profits are considered as transfer from consumer to firms. This condition will thus determine the IP policies towards domestic firms. Given the behavior of innovators (such that all innovations which yield a positive profit are undertaken), the benefit associated with new innovations is solely the consumer surplus that it will yield ex post.

By contrast, the optimal IP policy towards foreign innovators will balance the benefit from additional innovation abroad (for domestic consumers) with the fall in consumer surplus on existing foreign innovations. In this case, the profit, which accrues to foreign firms, is not counted as part of domestic welfare.

The condition for the optimal domestic IP policy in country i can then be written:

$$
\operatorname{CS}\left(\tilde{P}_{i}\right) \frac{\partial \tilde{k}_{i}}{\partial \tilde{P}_{i}}-\frac{\partial D W L\left(\tilde{P}_{i}\right)}{\partial \tilde{P}_{i}} k_{i}\left(\tilde{P}_{i}, y_{j}\right)=0, i=1,2
$$

The first term represents the benefit that is obtained from increasing IP rights in terms of additional consumer surplus. The second term 
Table 1. Independent IP policies

\begin{tabular}{lcc}
\hline \hline & $\mathrm{a}_{1}=\mathrm{a}_{2}=1$ & $\mathrm{a}_{1}=1.25, \mathrm{a}_{2}=1$ \\
\hline $\mathrm{P}_{1}$ & 0.301 & 0.401 \\
$\mathrm{y}_{1}$ & 0.129 & 0.215 \\
$\mathrm{P}_{2}$ & 0.301 & 0.276 \\
$\mathrm{y}_{2}$ & 0.129 & 0.067 \\
$\mathrm{k}^{*}$ & 0.323 & \\
$\mathrm{~W}$ & 0.259 & \\
\hline
\end{tabular}

represents the cost in terms of increasing the deadweight loss on existing products. Note that this formulation assumes that profits and consumer surplus are equally weighted by the government (so that the change in the sum of consumer surplus and profit is equal to the opposite of the change in the deadweight loss).

The condition for the optimal IP policy in country i toward foreign firms can be written;

$$
\operatorname{CS}\left(y_{i}\right) \frac{\partial k_{j}}{\partial y_{i}}-\frac{\partial \operatorname{CS}\left(y_{i}\right)}{\partial y_{i}} k_{j}\left(\tilde{P}_{j}, y_{i}\right)=0, i=1,2
$$

The uncoordinated outcome can then be derived by solving the four equations given in (1)-(2). It is easy to check that these conditions yield downward sloping reactions functions, such that the IP rights granted to domestic firms will fall as the IP rights that they obtain abroad increase. As one would expect, the IP rights granted to foreign firms are always less than those granted to domestic innovators. For the sake of illustration, table 1 reports the optimal IP rights, when markets are symmetric (with $a_{i}=1, i=1,2$ ) and in the case where market 1 is larger, $a_{1}=1.25, a_{2}=1$.

The comparison between asymmetric and symmetric outcomes confirms that large countries have a stronger incentive to grant property rights to foreign firms - simply because they have a stronger effect in triggering marginal innovations.

Table 1 also reports the range of innovation that is undertaken in each country $\left(\mathrm{k}^{*}\right)$ in equilibrium, as well as the level of welfare, for further reference.

(iv) National Treatment

Under National Treatment, domestic and foreign firms have to be treated alike. In other words, we have that $\tilde{P}_{i}=y_{i}, i=1,2$. The 
optimal IP right in country $\mathrm{i}$ will then balance the benefit for domestic consumers of additional innovations at home plus the benefit for domestic customers of additional innovations induced abroad with the deadweight loss on existing innovations at home and the loss of (domestic) consumer surplus on existing innovations from abroad.

The condition for an optimal IP policy under national treatment is then written:

$$
\begin{gathered}
\operatorname{CS}\left(\tilde{P}_{i}\right) \frac{\partial k_{i}}{\partial \tilde{P}_{i}}-\frac{\partial D W L\left(\tilde{P}_{i}\right)}{\partial \tilde{P}_{i}} k_{i}\left(\tilde{P}_{i}, \tilde{P}_{j}\right)+\operatorname{CS}\left(\tilde{P}_{i}\right) \frac{\partial k_{j}}{\partial \tilde{P}_{i}} \\
-\frac{\partial C S\left(\tilde{P}_{i}\right)}{\partial \tilde{P}_{i}} k_{j}\left(\tilde{P}_{j}, \tilde{P}_{i}\right)=0, \quad i=1,2
\end{gathered}
$$

The reactions functions implicitly defined by these equations are downward sloping. One can also check that the equilibrium IP rights which solve these two equations are in between the domestic and foreign IP rights defined above under the assumption that IP policies are independent. To illustrate, assuming that countries are symmetric (with $a_{i}=1, i=1,2$ ), one obtains that $\tilde{P}_{i}=5 / 4-\sqrt{17} / 4 \simeq 0.219$. In the context of this example, the level of innovation which is undertaken and the welfare are given by : $\mathrm{k}^{*}=0.342, \mathrm{~W}=0.267$.

The comparison between the outcomes under independent IP policies and national treatment is striking. Under national treatment, government has to offer the same rights to domestic and foreign innovators despite the fact that IP rights to the latter yield much lower perceived returns. As a consequence, the marginal returns from IP rights fall relative to marginal returns from domestic rights. The aggregate right increases only marginally and as a consequence, the range of innovation hardly increases. The level of welfare is also barely changed.

One should possibly not pay too much attention to the results that aggregate IP rights, the range of innovation and welfare do not change significantly with national treatment, relative to the independent solution, as these results are likely affected by the shape of the demand function. However, the observation that national treatment is ineffective because it prevents government from discriminating between IP rights with different perceived returns and as a consequence leads to a sharp fall on the IP rights granted to domestic firms deserves attention. 
(v) Mutual recognition

In a regime of mutual recognition, the domestic government has to grant to foreign firms the same treatment that they receive at home. In the context of our model, this implies that $y_{i}=\tilde{P}_{j}, i=1,2$. In this environment, national government can effectively make sure that the same IP rights are granted to domestic innovators, irrespective of where the innovation is sold. Unlike what happens under national treatment, domestic government cannot affect the profitability of foreign innovations but rather raise contributions to domestic innovations from foreigners.

The optimal IP right will then balance the benefit of additional innovations at home with the deadweight loss on existing innovations, taking into account that an increase in domestic IP rights will be matched by an increase in foreign IP rights on domestic innovations. The condition for optimal IP rights is then written:

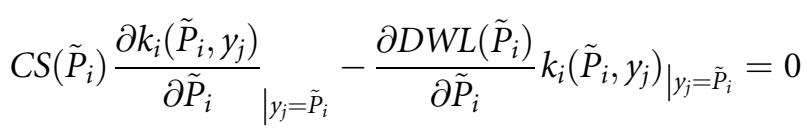

Interestingly, this condition is equivalent to the condition for optimal IP rights that would be chosen by a government which considers all external effects across markets, when the markets are symmetric. This condition can be written as:

$$
2 C S(\tilde{P}) \frac{\partial k(\tilde{P})}{\partial \tilde{P}}-2 \frac{\partial D W L(\tilde{P})}{\partial \tilde{P}} k(\tilde{P})=0
$$

When markets are symmetric, we have that $\partial k(\tilde{P}) / \partial \tilde{P}=$ $\partial k_{i}\left(\tilde{P}_{i}, y_{j}\right) / \partial \tilde{P}_{i} y_{j}=\tilde{P}_{i}$ and $k(\tilde{P})=k_{i}\left(\tilde{P}_{i}, y_{j}\right)_{\mid y_{j}=\tilde{P}_{i}}$ so that the two conditions are equivalent.

To illustrate, assuming that countries are symmetric (with $a_{i}=1, i=1,2$ ), one obtains that under mutual recognition (and the fully coordinated solution) $\tilde{P}_{i}=1 / 3$. The level of innovation which is undertaken and the welfare are then given by: $\mathrm{k}^{*}=0.44, \mathrm{~W}=0.296$.

The intuition behind the effectiveness of mutual recognition can be expressed as follows: mutual recognition forces the foreign country to adopt the same IP protection towards domestic firms. But in a symmetric world, the level of protection that the foreign country is "forced" to adopt is also the level of IP protection that foreigners should have adopted if they were taking external effects into account. 
Hence, mutual recognition effectively mimics the outcome that would be chosen by a central authority.

One can also expect that in an asymmetric world, the equivalence will no longer hold. Presumably, large countries will induce smaller ones to choose an IP policy which is more extensive than what they would choose if they were taking external effects into account and vice versa. This could lead to excessively broad protection in large countries and excessively low protection in small ones.

\section{References}

Beebe, B. (2003), The semiotic analyis of trademark law, Mimeo, Benjamin Cardozo School of Law, Yeshiva University.

Coombe, R. (1998), The Cultural Life of Intellectual Properties: Authorship, Appropriation, and the Law. Durham, NC: Duke University Press.

Economides, N. (1984), The economics of trademarks, WP 21, Columbia.

Grossman, G. and E. Lai (2002), International protection of intellectual property, NBER Working Paper $\mathrm{N}^{\circ} 8704$.

Howse, R. (2000), Adjudicative Legitimacy and Treaty Interpretation in International Trade Law: The Early Years of WTO Jurisprudence, in The EU, the WTO, and the NAFTA: Towards a Common Law of International Trade? edited by J. H. H. Weiler, 35-69. The Collected Courses of the Academy of European Law, 9/1. Oxford: Oxford University Press.

Howse, R. and K. Nicolaidis (2003), Enhancing WTO Legitimacy: Constitutionalization or Global Subsidiarity? Governance 16, no. 1 (2003): 73-94.

Howse, R. and E. Tuerk (2001), The WTO Impact on Internal Regulations - A Case Study of the Canada-EC Asbestos Dispute, in The EU and the WTO: Legal and Constitutional Issues, edited by G. de Búrca and J. Scott, 283-328. Oxford: Hart Publishing.

Landes, W. and R. Posner (1987), Trademark law: an economic perspective, The Journal of Law and Economics, XXX (2), 265-310.

Landes, W. and R. Posner (2003), The Economic Structure of Intellectual Property Law. Cambridge, MA: The Belknap Press of Harvard University Press.

Maskus, K. (2000), Intellectual Property Rights in the Gobal Economy. Washington, DC: The Institute for International Economics.

Nordhaus, W. (1969), Invention, Growth and Welfare: a Theoretical Treatment of Technological Change. Cambridge, MA: MIT Press.

Scotchmer, S. (2002), The political economy of intellectual property treaties, NBER Working Paper $\mathrm{N}^{\circ} 9114$.

Van Wezel Stone, Katherine (1999), To the Yukon and Beyond: Local Laborers in a Global Labor Market. Journal of Small and Emerging Business Law. 